IOSR Journal of Pharmacy

ISSN: 2250-3013, www.iosrphr.org

\||| Volume 2 Issue 5 ||| Sep-Oct. 2012\|\| PP.31-37

\title{
Formulation and Evaluation of Transdermal Patches of Propranolol Hydrochloride
}

\author{
V.N.L. Sirisha*, P. Kirankumar, M.ChinnaEswaraiah, \\ Anurag Pharmacy College, Affliated to JNTUH, Kodad, Nalgonda-Dt, Andhra Pradesh.
}

\begin{abstract}
The purpose of this research was to develop a matrix-type transdermal therapeutic system containing drug propranolol hydrochloride with different ratios of hydrophobic (eudragit's) polymeric systems by the solvent evaporation technique by using $30 \% \mathrm{w} / \mathrm{w}$ of di-butyl phthalate to the polymer weight, incorporated as plasticizer. The physicochemical compatibility of the drug and the polymers studied by infrared spectroscopy suggested absence of any incompatibility. Formulated transdermal films were physically evaluated with regard to thickness, weight variation, drug content, flatness, folding endurance moisture. All prepared formulations indicated good physical stability. In-vitro permeation studies of formulations were performed by using Franz diffusion cells.It shown that drug release follows zero order and the mechanism of release is diffusion from the polymer.
\end{abstract}

Keywords—Propranolol hydrochloride, Transdermal Film, In-vitro permeation study.

\section{INTRODUCTION}

Transdermal drug administration generally refers to topical application of agents to healthy intact skin either for localized treatment of tissues underlying the skin or for systemic therapy. For transdermal products the goal of dosage design is to maximize the flux through the skin into the systemic circulation and simultaneously minimize the retention and metabolism of the drug in the skin ${ }^{[1]}$.

Transdermaldrug delivery has many advantages over the oral route of administration such as improving patient compliance in long term therapy, bypassing first-pass metabolism, sustaining drug delivery, maintaining a constant and prolonged drug level in plasma, minimizing inter- and intra patient variability, and making it possible to interrupt or terminate treatment when necessary ${ }^{[2,3]}$ Propranolol, the prototype of the beta-adrenergic receptor antagonists, is aactivity. Propanolol is a racemic compound; the l-isomer is responsible for adrenergic blocking competitive, non-selective beta-blocker similar to nadolol without intrinsic sympatho mimetic activity.

Propranolol competes with sympatho mimetic neurotransmitters such as catechol amines for binding at beta(1)-adrenergic receptors in the heart, inhibiting sympathetic stimulation.This results in a reduction in resting heart rate, cardiac output, systolic and diastolic blood pressure, and reflex orthostatichypotension ${ }^{(4)}$

\section{MATERIALS AND METHODS}

Propranolol hydrochloride was received as a gift samples from Bhari Pharmaceticals, hyderabad, India (Ahmadabad, India).the polymers are also obtained from bharipharmaceuticals. Other materials used in the study (chloroform, methanol, dichloromethane, glycerol, potassium dihydrogen phosphate, etc.) were of analytical grade. Double-distilled water was used throughout the study.

\section{INVESTIGATION OF PHYSICOCHEMICAL COMPATIBILITY OF DRUG AND} POLYMER

The physicochemical compatibility between propranolol hydrochloride and polymers used in the films was studied by using fourier transform infrared (FTIR- 8300, Shimadzu Co., Kyoto, Japan) spectroscopy.

The infrared (IR) spectra were recorded using an FTIR by the $\mathrm{KBr}$ pellet method and spectra were recorded in the wavelength region between 4000 and $400 \mathrm{~cm}-1$. The spectra obtained for propranolol hydrochloride, polymers, and physical mixtures of propranolol hydrochloride with polymers were compared ${ }^{(5)}$.

\subsection{Mercury substrate method:}

\section{PREPARATION OF TRANSDERMAL FILMS}

The polymers, Eudragit L100 and Eudragit S100, Eudragit RSPO were taken in required quantity as shown in the table. About $20 \mathrm{ml}$ of solvent mixture of dichloromethane: methanol (1:1) was added and shaked to prevent the formation of lumps, and then kept aside for swelling of polymers. And after complete solublization 
of polymers in mixture of solvent, added required quantity of dibutyl phthalate to this mixture, and vertexed. Finally weighed quantity of propranolol hydrochloride added to the polymer solution and mixed well. It was setaside for some time to exclude any entrapped air and was then transferred into a previously cleaned Petri plate $\left(70 \mathrm{~cm}^{2}\right)$ and then this was kept aside for solvent evaporation. The rate of solvent evaporation was controlled by inverting a glass funnel over the petri plate. After overnight, the dried films were taken out and stored in a dessicator $^{(6)}$.

Fig.No:1. Matrix Diffusion-Controlled Systems

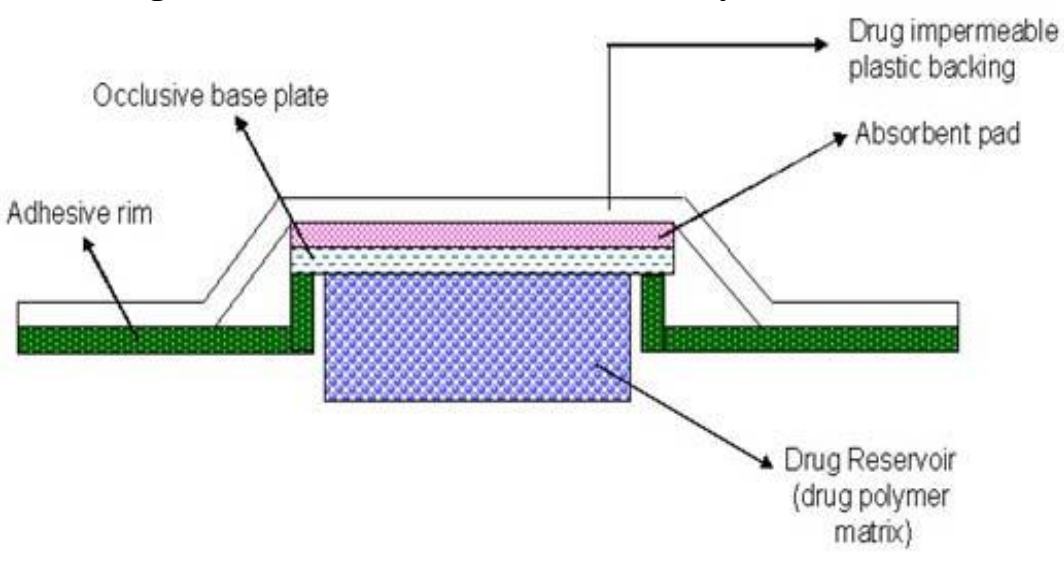

Table. No. 1: Formulation trials of Propranolol hydrochloride Patches

\begin{tabular}{|c|c|c|c|c|c|c|c|c|c|c|c|}
\hline $\begin{array}{l}\text { Ingredients } \\
\text { (in mg or ml) }\end{array}$ & F1 & F2 & F3 & F4 & F5 & F6 & F7 & F8 & F9 & $\begin{array}{l}\text { F1 } \\
\text { 0 }\end{array}$ & $\begin{array}{l}\text { F1 } \\
1\end{array}$ \\
\hline $\begin{array}{l}\text { Propranolol } \\
\text { hydrochloride }\end{array}$ & 350 & 350 & 350 & 350 & 350 & 350 & 350 & 350 & 350 & 350 & 350 \\
\hline Eudragit-L100 & 200 & $\begin{array}{l}150 \\
0\end{array}$ & 100 & - & - & 500 & - & 500 & 650 & - & 750 \\
\hline Eudragit-S100 & - & - & - & $\begin{array}{l}100 \\
0\end{array}$ & - & 500 & 500 & - & 350 & 350 & - \\
\hline Eudragit RSPO & - & - & - & - & $\begin{array}{l}100 \\
0\end{array}$ & - & 500 & 500 & - & 650 & 250 \\
\hline $\begin{array}{l}\text { Dichloromethan } \\
\text { e }\end{array}$ & 10 & 10 & 10 & 10 & 10 & 10 & 10 & 10 & 10 & 10 & 10 \\
\hline Methanol & 10 & 10 & 10 & 10 & 10 & 10 & 10 & 10 & 10 & 10 & 10 \\
\hline $\begin{array}{l}\text { Dibutyl } \\
\text { phthalate(in \% } \\
\text { w/v) }\end{array}$ & 30 & 30 & 30 & 30 & 30 & 30 & 30 & 30 & 30 & 30 & 30 \\
\hline
\end{tabular}

\subsection{Physical evaluations:}

\section{EVALUATIONS OF PATCHES}

\subsubsection{Thickness:}

The thickness of films was measured by digital Vernier calipers with least count $0.001 \mathrm{~mm}$. The thickness uniformity was measured at five different sites and average of five readings was taken with standard deviation $^{(6)}$.

\subsubsection{Folding endurance:}

The folding endurance was measured manually for the prepared films. A strip of film $(4 \times 3 \mathrm{~cm})$ was cut evenly and repeatedly folded at the same place till it broke. The number of times the film could be folded at the same place without breaking gave the exact value of folding endurance ${ }^{(6)}$.

\subsubsection{Weight variation:}

The three disks of $2 * 2 \mathrm{~cm} 2$ was cut and weighed on electronic balance for weight variation test. The test was done to check the uniformity of weight and thus check the batch- to- batch variation ${ }^{(6)}$.

\subsubsection{Drug content Determination:}


The prepared drug contained patches specified surface area $\left(2 \mathrm{~cm}^{2}\right)$ were cut and dissolved in $(5 \%$ of methanol contained) $100 \mathrm{ml}$ of $\mathrm{pH} 7.4$ phosphate buffer, and vigorously shaked for $12 \mathrm{hrs}$, and then sonicated for 15 minutes, centrifuged at $5000 \mathrm{rpm}$ for $30 \mathrm{~min}$. Filter the drug contained polymeric solution through 42 number whatmann filter paper, then $1 \mathrm{ml}$ of the filtrate was taken in a test tube and dilute it for five times with same solvent by using double beam UV-Visible spectrophotometer to determined drug content at $\lambda \max 428 \mathrm{~nm}$. Respected Placebo patch was taken as a blank solution ${ }^{(6)}$.

\subsubsection{Surface pH:}

Surface $\mathrm{pH}$ of the patches was determined by the method described by Bottenberg et al. The patches were allowed to swell by keeping them incontact with $0.5 \mathrm{ml}$ of double distilled water for 1 hour in glass tubes. Thesurface $\mathrm{pH}$ was then noted by bringing a combined glass electrode nearthe surface of the patch and allowing it to equilibrate for 1 minute ${ }^{(7)}$.

Table 2: Evaluation of transdermal patches

\begin{tabular}{|c|c|c|c|c|c|c|c|}
\hline $\begin{array}{l}\text { Formulat } \\
\text { ion Code }\end{array}$ & $\begin{array}{l}\text { Weight } \\
\text { variation } \\
(\mathrm{mg})\end{array}$ & $\begin{array}{l}\text { Thickn } \\
\text { ess } \\
(\mu \mathrm{m})\end{array}$ & $\begin{array}{l}\text { Folding } \\
\text { endura } \\
\text { nce }\end{array}$ & $\begin{array}{l}\text { Flatnes } \\
\text { s }\end{array}$ & $\begin{array}{l}\text { Appear } \\
\text { ence }\end{array}$ & $\begin{array}{l}\text { \% } \\
\text { Drug } \\
\text { Conten } \\
\text { t }\end{array}$ & $\begin{array}{l}\text { Surfac } \\
\text { e pH }\end{array}$ \\
\hline $\mathrm{F} 1$ & $81 \pm 1.05$ & $\begin{array}{l}287.6 \pm 2 \\
.46\end{array}$ & $\begin{array}{l}65.33 \pm 5 \\
.03\end{array}$ & 100 & $\begin{array}{l}\text { Transpa } \\
\text { rent }\end{array}$ & $\begin{array}{l}97.4 \pm .4 \\
5\end{array}$ & 5.3 \\
\hline $\mathrm{F} 2$ & $63.33 \pm 1.5$ & $\begin{array}{l}240.4 \pm 2 \\
.51\end{array}$ & $\begin{array}{l}115.66 \pm \\
4.04\end{array}$ & 100 & $\begin{array}{l}\text { Transpa } \\
\text { rent }\end{array}$ & $\begin{array}{l}97.98 \pm . \\
42\end{array}$ & 5.1 \\
\hline F3 & $52 \pm 2.00$ & $\begin{array}{l}192.6 \pm 1 \\
.75\end{array}$ & $\begin{array}{l}141.66 \pm \\
3.78\end{array}$ & 100 & $\begin{array}{l}\text { Transpa } \\
\text { rent }\end{array}$ & $99 \pm .255$ & 5.8 \\
\hline F4 & $\begin{array}{l}51.66 \pm 1.5 \\
2\end{array}$ & $\begin{array}{l}195.3 \pm 2 \\
.40\end{array}$ & $\begin{array}{l}127.33 \pm \\
4.72\end{array}$ & 100 & $\begin{array}{l}\text { Transpa } \\
\text { rent }\end{array}$ & $\begin{array}{l}97.37 \pm \\
48\end{array}$ & 5.6 \\
\hline F5 & $53.50 \pm 20$ & $\begin{array}{l}174.3 \pm 1 \\
.31\end{array}$ & $\begin{array}{l}147 \pm 5.5 \\
6\end{array}$ & 100 & $\begin{array}{l}\text { Transpa } \\
\text { rent }\end{array}$ & 96.00 & 5.4 \\
\hline F6 & 48.00 & $\begin{array}{l}199.3 \pm 3 \\
.20\end{array}$ & $\begin{array}{l}124.33 \pm \\
5.03\end{array}$ & 100 & $\begin{array}{l}\text { Transpa } \\
\text { rent }\end{array}$ & $\begin{array}{l}97.52 \pm 1 \\
.4\end{array}$ & 5.2 \\
\hline F7 & $\begin{array}{l}48.33 \pm 1.5 \\
2\end{array}$ & $\begin{array}{l}187.6 \pm 2 \\
.40\end{array}$ & $\begin{array}{l}160 \pm 4.5 \\
8\end{array}$ & 100 & $\begin{array}{l}\text { Transpa } \\
\text { rent }\end{array}$ & $\begin{array}{l}97.99 \pm . \\
79\end{array}$ & 5.5 \\
\hline F8 & $\begin{array}{l}53.33 \pm 1.5 \\
2\end{array}$ & $\begin{array}{l}191.5 \pm 2 \\
.36\end{array}$ & $\begin{array}{l}160.66 \pm \\
4.5\end{array}$ & 100 & $\begin{array}{l}\text { Transpa } \\
\text { rent }\end{array}$ & $\begin{array}{l}98.82 \pm . \\
39\end{array}$ & 5.6 \\
\hline F9 & $51 \pm 2.00$ & $\begin{array}{l}194.3 \pm 1 \\
.31\end{array}$ & $\begin{array}{l}132.33 \pm \\
5.50\end{array}$ & 100 & $\begin{array}{l}\text { Transpa } \\
\text { rent }\end{array}$ & $\begin{array}{l}97.9 \pm .7 \\
0\end{array}$ & 5.3 \\
\hline F10 & $\begin{array}{l}52.66 \pm 2.5 \\
1\end{array}$ & $\begin{array}{l}197.3 \pm 3 \\
.32\end{array}$ & $\begin{array}{l}147 \pm 5.5 \\
6\end{array}$ & 100 & $\begin{array}{l}\text { Transpa } \\
\text { rent }\end{array}$ & $\begin{array}{l}98.95 \pm . \\
43\end{array}$ & 5.8 \\
\hline F11 & $49 \pm 2$ & $\begin{array}{l}198.7 \pm 2 \\
.26\end{array}$ & $\begin{array}{l}155.66 \pm \\
6.50\end{array}$ & 100 & $\begin{array}{l}\text { Transpa } \\
\text { rent }\end{array}$ & $\begin{array}{l}97.8 \pm .5 \\
2\end{array}$ & 5.7 \\
\hline
\end{tabular}

\section{IN-VITRO DRUG DIFFUSUSION STUDY}

The drug diffusion studies through dialysis(cellophane) membrane experiments were conducted by using vertical type diffusion cell (Franz type) having receptor compartment $15 \mathrm{ml}$ volume with $2 \mathrm{~cm}^{2}$ area. The receptor compartment was filled $15 \mathrm{ml}$ of phosphate buffer $\mathrm{pH} 7.4$; the activated dialysis membrane was mounted on the flange of the diffusion cell receptor compartment. The prepared Transdermal patch with surface area $2 \mathrm{~cm}^{2}$ placed on center of membrane, the donor compartment was then placed in position and the two valves of the cell clamped together. The whole assembly was kept on a magnetic stirrer and solution in the receptor compartment was constantly and continuously stirred using a magnetic bead and at $32 \pm 1{ }^{\circ} \mathrm{C}$ maintained ${ }^{(8)}$.

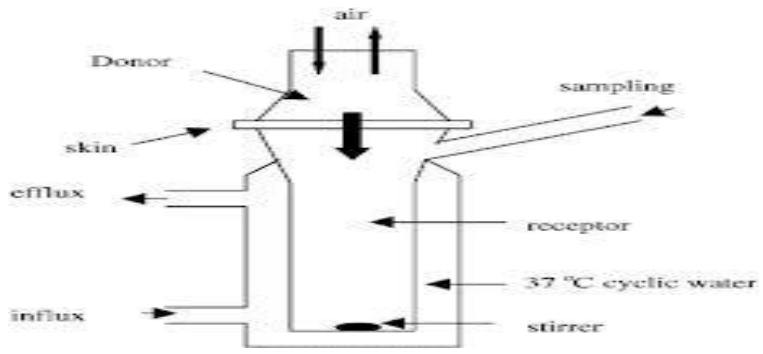

Fig. No. 2: Franz-diffusion cell 


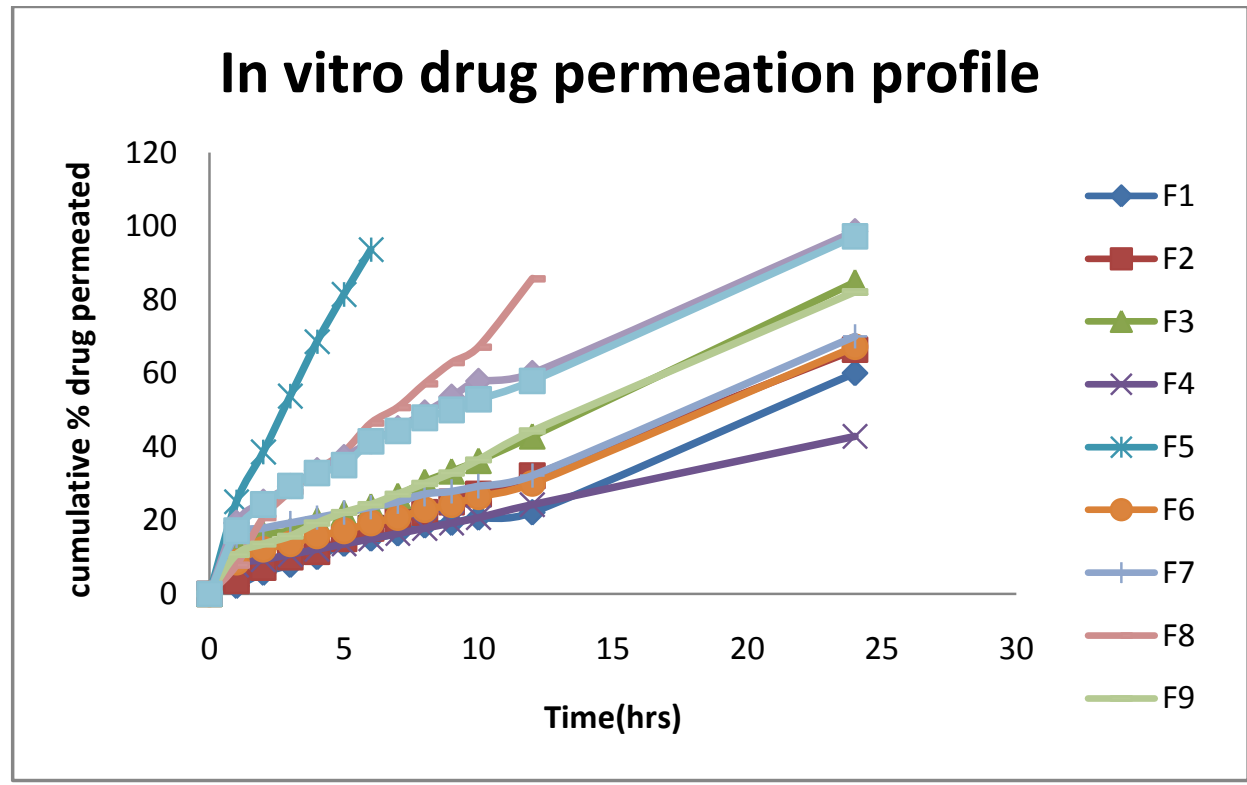

Fig.No.3: In vitro drug permeation profile

7. Kinetic models for Propranolol hydrochloride

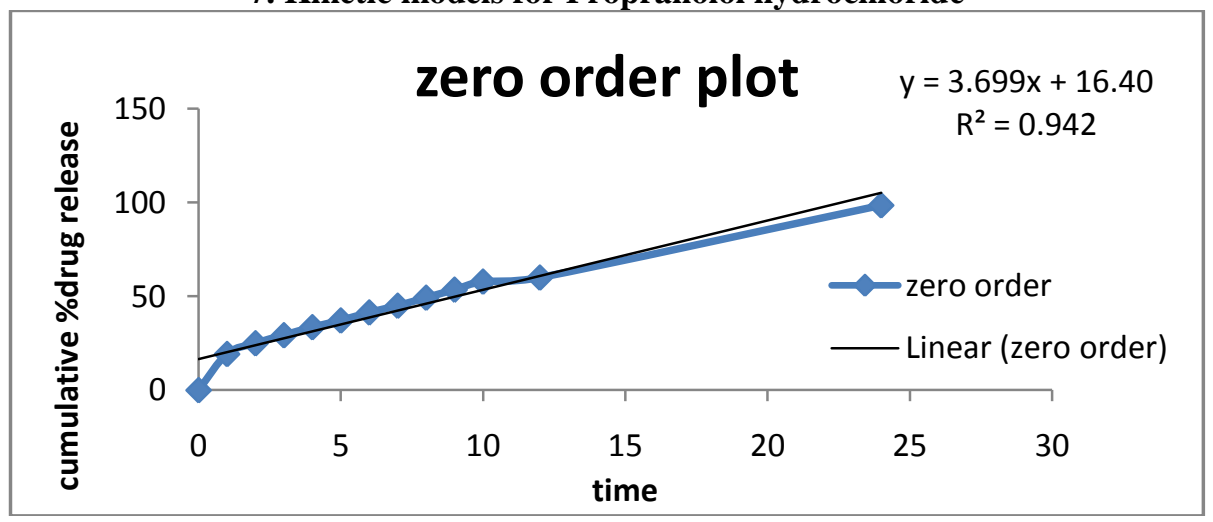

Fig.No.4: Zero order plot of Propranolol hydrochloride F-10



Fig.No.5: First order plot of propranolol hydrochloride F-10 


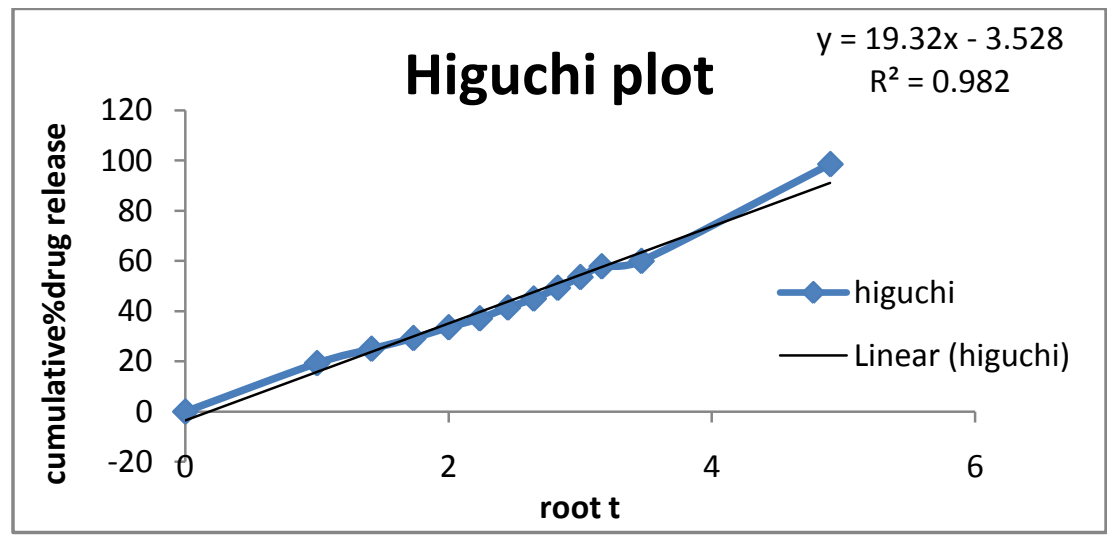

Fig.No.6: Higuchi plot of propranolol hydrochloride F-10

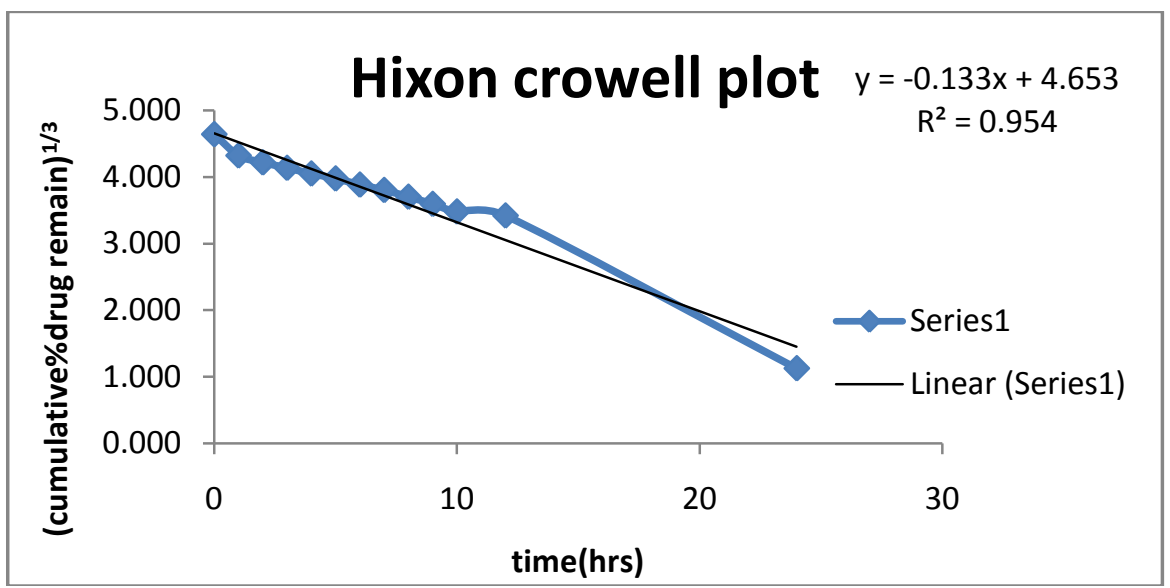

V.N. Formulation and evaluation of transdermal patches of propranololhydrochloride2515

Fig.No.7: Hixon crowell plot of propranolol hydrochloride F-10



Fig.No.8: Kores-meyer Peppas plot of propranolol hydrochloride F-10

\section{DISCUSSION}

Hypertension is common disorder that, if not effectively treated results in a greatly increased probability of coronary thrombosis, stroke and renal failure until about 1950, there wasno effective treatment, and the development of antihypertensive drugs, which restore healthy life expectancy has been a major therapeutic success in the treatment of hypertension.Propranolol hydrochloride is a non-selective beta blocker, mainly used in the management of various cardiovascular disorders. It reduces theoxygen requirement of the heart at any level of effort by blocking catecholamine induced increase in the heart rate, systolic blood pressure, 
thevelocity and extent of myocardial contraction. Our present work comprises the formulation and evaluation of propranolol hydrochloridetransdermal patches for sustained or extended release for a prolonged period of time.

Initially the drug was tested by UV to know their significant absorption maximum which can be used

for the diffusion study of the drug. The compatibility studies of the drug with excipients indicate no characteristic visual changes and no additional peaks were observed during FT-IR studies.

Totally, eleven formulation trials (F-1 to F-11) were done with the aim to achieve the successful matrix type propranolol hydrochloride transdermal patches. The blend trials prepared for the drug was evaluated for various physical parameters and content uniformity of drug by UV.

Eudragits like eudragit S-100, L-100, RSPO used as controlled release polymers in the formulation of propranolol hydrochloride transdermal patches individually and in combination. Methanol and Dichloromethane used as solvents. Di-butyl phthalate used as plasticizer.

All the trials were formulated as patches. All the patches were evaluated for weight variation, thickness, drug content, folding endurance, surface $\mathrm{p}^{\mathrm{H}}$ and in-vitro drug release.

All formulations were transparent in appearance.

The formulations F1, F2 were varying in thickness when compared to other formulations which is due to the variation in the polymer concentration which shows the increase in polymer concentration increases the thickness of patch. For all other formulations it was found to be in between 187 to $199 \mu \mathrm{m}$.All formulations from $\mathrm{F} 3$ to F11 shows weight variation in between 48 to $52 \mathrm{mg}$.Folding endurance from formulations F2 to F11 was found to be in between 115 to 155.which can withstand the foldings of the skin.All formulation shows $\mathrm{p}^{\mathrm{H}}$ in the range of 5.1 to 5.8.so we can expect no skin irritation.All formulations shows good \% drug content in between 97.4 to 99 .

The diffusion studies of the patches were carried out in the phosphate buffer 7.4 PH. The formulation F-10 was found to be best when compared with all the evaluation values of other formulations.

Thus the diffusion data obtained was fitted to various mathematical kinetic models such as zero order, first order, higuchi plot and peppa's plot. The in-vitro diffusion data of the formulation F-10 was found to be nearer to innovator's drug release and from the result.From the kinetic data it was found that drug release follows zero order release by diffusion technique from the polymer.

\section{CONCLUSION}

In the present investigation an attempt has been made to design and develop the formulation of Propranolol hydrochloride patches using different types of eudragits by solvent evaporation technique and mercury substrate method. The drug used isthe best studied for therapy in treating hypertension.

Propranolol hydrochloride was successfully formulated as controlled release transdermal patches, which prevents the frequency of administration and gives good patient compliance.From the experimental results obtained, F-10 formulation has been selected as the best formulation among all the other formulations. The in-vitro drug diffusion study from the formulation was found to be controlled release. All the evaluation parameters obtained from the best formulation were found to be satisfactory. The data obtained from the in-vitro release studies were fitted to various kinetic models like zero order, first order, Higuchi model and peppas model. From the kinetic data it was found that drug release follows zero order release by diffusion technique from the polymer.

Based on the observations, it can be concluded that the attempt of formulation and evaluation of thePropranolol hydrochloride patches was found to be successful in the release of the drug for an extended period of $24 \mathrm{hrs}$. 


\section{[1]. REFERENCES}

[2]. Misra AN. Controlled and Novel Drug Delivery. In: N.K. Jain(Eds.), Transdermal Drug Delivery New Delhi, India: CBS Publisher and Distributor. 1997. 100-101.

[3]. Chien Y W Transdermal therapeutic system. In: Robinson, JR, Lee V H L., eds. Controlled Drug Delivery Fundamentals and Applications 2nd ed. New York: Marcel Dekker, Inc. 1987; 524-552.

[4]. Keith AD. Polymer matrix consideration for transdermal devices. Drug Dev Ind. 1983; 9: 605-621.

[5]. 4. Wilson K J W, Waugh A. Eds, "Ross and Wilson: Anatomy And Physiology In

a. $\quad$ Health and Illness", 8th Edition, Churchill Livingstone. 1996:360-366.

[6]. 5. Rakesh P. Patel, Grishma Patel, Ashok Baria,Formulation and evaluation of transdermal patch of Aceclofenac,

[7]. International Journal of Drug Delivery 1(2009) 41-51.

[8]. 6. J.Ashokkumar, Nikhilapullakandam,S.Lakshmanaprabu,V.Gopal.Transdermal drug delivery

[9]. system:Anoverview.IJPSRR,ISSN 0976-044X(2010)49-54.

[10]. 7. MeenakshiBharkatiya,Rajeshkumar ,MahipBhatnagar,Development and charecterisation of transderma patches of Metoprololtartrate.Asian journal of pharmaceutical and clinical research,2010,130-134

[11]. 8. Yogesh M. Amgaokar, Rupesh V. Chikhale, Updesh B. Lade,Dinesh M. Biyani, Milind J. Umekar, design,

[12]. formulation and evaluation of transdermal drug delivery system of budesonide, Digest Journal of

[13]. Nanomaterials and Biostructures Vol. 6, No 2, April - June 2011, p. 475-497.

[14]. 9. Sankar V, Sivanand V, Ravichandran V. Design and evaluation of nifedipine transdermal patches. Ind J Pharm

[15]. Sci. 2003; 65(5):510-5.

[16]. 10. Murthy S N, Shoba Rani, Hiremath R, Formulation and evaluation of controlled release transdermal patches of

[17]. theophylline-salbutamol sulphate, Drug Dev Ind Pharm, Online published 30/09/2001, 1057-62.

[18]. 11. Prashant M, satturwar S, Fulzele V and avinash K. dorle evaluation of polymerized rosin for the formulation

[19]. and development transdermal drug delivery systems. AAPS Pharmscitech. 2005; 6(4):48-53.

[20]. 12. Manvi FV, Dandagi PM, Gadad AP. Formulation of a transdermal drug delivery system of ketotifen fumarate.

[21]. Ind J Pharm Sci. 2003;65(3):239-43.

[22]. 13. Agrawal SS, Munjal P. Permeation studies of atenololand metoprolol tartarate form three different polymer

[23]. matrices for transdermal delivery. Ind J Pharm Sci. 2007: 535-9.

[24]. 14. Gwak H S, Oh IS, Chun I K, transdermal delivery of ondansetron hydrochloride: effects of vehicles and

[25]. penetration enhancers, Drug Dev Ind Pharm, 30, (2), Feb 2004, 187-94.

[26]. 15. Kikwai L, Kanikkannan N, Babu RJ, Singh M. Effect of vehicles on the transdermal delivery of melatonin

[27]. across porcine skin in vitro. J Control Release. 2002 Oct 4;83(2):307-11. 